\title{
Immunohistochemical localization and bacteriostatic properties of an iron-binding protein from bronchial mucus
}

\author{
P. L. MASSON, J. F. HEREMANS, J. J. PRIGNOT, AND G. WAUTERS \\ From the Research Department of Internal Pathology, Department of Internal Medicine, Pneumology \\ Unit (Cliniques Universitaires St-Pierre), and the Bacteriological Institute, University of Louvain, \\ Louvain (Leuven), Belgium
}

Sputum from patients with various respiratory diseases is known to contain a protein with ironbinding properties (Biserte, Havez, and Cuvelier, 1963) which is absent from the serum and is in all respects identical with a similar red-coloured protein from human milk.

This component was called red milk protein by Johansson (1958), lactosiderophilin by Montreuil, Tonnelat, and Mullet (1960), and lactotransferrin or lactoferrin by Blanc and Isliker (1961a, b). The last-mentioned name, lactoferrin, seems preferable, since it avoids any confusion between the iron-binding protein from secretions and the structurally unrelated iron-binding protein, transferrin, which occurs in the serum.

Sputum cannot be taken to represent a pure sample of bronchial secretions, since it unavoidably contains some saliva. Since the latter secretion has also been shown to contain lactoferrin (Masson, Carbonara, and Heremans, 1965), the original studies by Biserte et al. (1963) left some doubt as to the occurrence of this iron-binding protein in genuine bronchial mucus, although the authors concluded otherwise. However, recent work from our laboratory (Masson, Heremans, and Prignot, 1965b) appears to have shown that lactoferrin does occur among the components of bronchial aspirates collected during bronchoscopy, as well as in bronchial washings obtained during anaesthesia. One of the aims of the present investigation was to confirm the genuine bronchial origin of this protein by demonstrating its presence in the bronchial epithelium and/or its glandular appendages.

The iron-binding protein from the serum, transferrin, is known to display a marked bacteriostatic effect on microbial strains strongly dependent on ionized iron (Schade, 1961). It was tempting, therefore, to investigate the iron-binding protein from sputum with respect to similar properties. This was the subject of the second part of the present study.

\section{MATERIALS AND METHODS}

IMMUNOHISTOCHEMICAL METHODS Specimens from macroscopically normal bronchial areas were obtained from eight patients by biopsy during either bronchoscopy or thoracic surgery. All samples were snapfrozen in dry ice, immediately after removal, and frozen sections were prepared using a Bright-Pearse refrigerated microtome.

Immunohistochemical studies were carried out by means of a fluorescein-conjugated antiserum specifically directed against human lactoferrin (Masson, Heremans, and Prignot. 1965a). This antiserum was obtained from a rabbit which had received a series of intramuscular injections with purified lactoferrin from human milk. Before use, the antiserum was absorbed with normal human serum as well as with human erythrocytes $(\mathbf{R h}+, \mathbf{A B})$. When tested by means of immunoelectrophoresis, the reagent thus obtained proved to be specific for lactoferrin and devoid of any activity against serum proteins or blood-group antigens. The frozen sections were affixed on microscope slides, air-dried, fixated by means of absolute methanol for 3 minutes, washed with two successive baths of buffered saline $(p H$ 7.2), and incubated with a drop of fluorescein-labelled antiserum. After examination under ultraviolet light, the sections were stained by means of the periodic acidSchiff technique, which earlier experience had proved to be the only satisfactory procedure applicable to such material.

BACTERIOLOGICAL TECHNIQUE Filter paper discs of the type used in routine bacteriological work were soaked in a $0.5 \%(w / v)$ solution of lactoferrin isolated from human milk by means of the method described by Blanc and Isliker (1961b). The solvent 


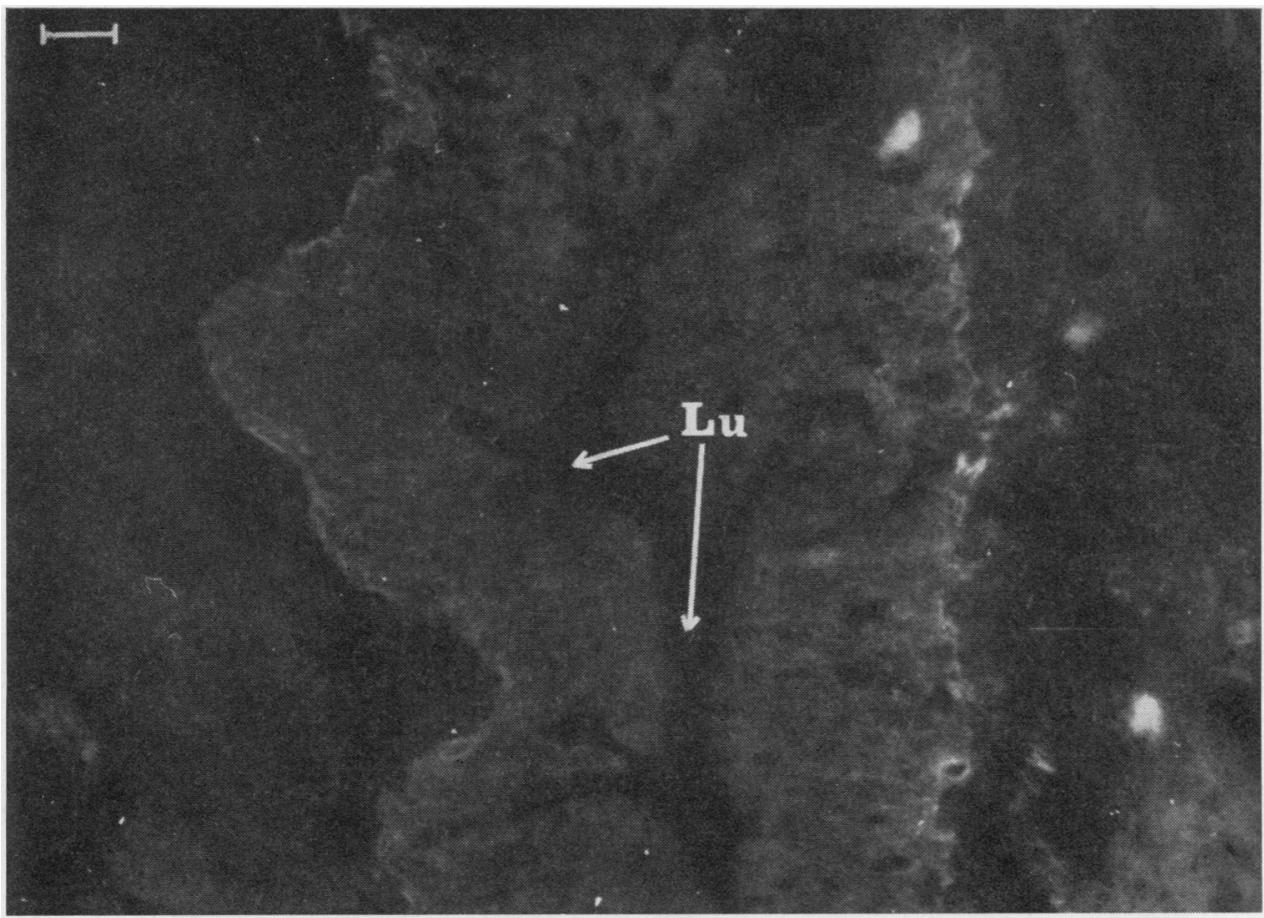

FIG. 1. Bronchial biopsy stained with fluorescein-labelled antiserum, photographed under ultraviolet illumination. This section passes through the neck of a gland (Lu=Lumen). The surface epithelium does not contain any fluorescent material (calibration $20 \mu$ ).

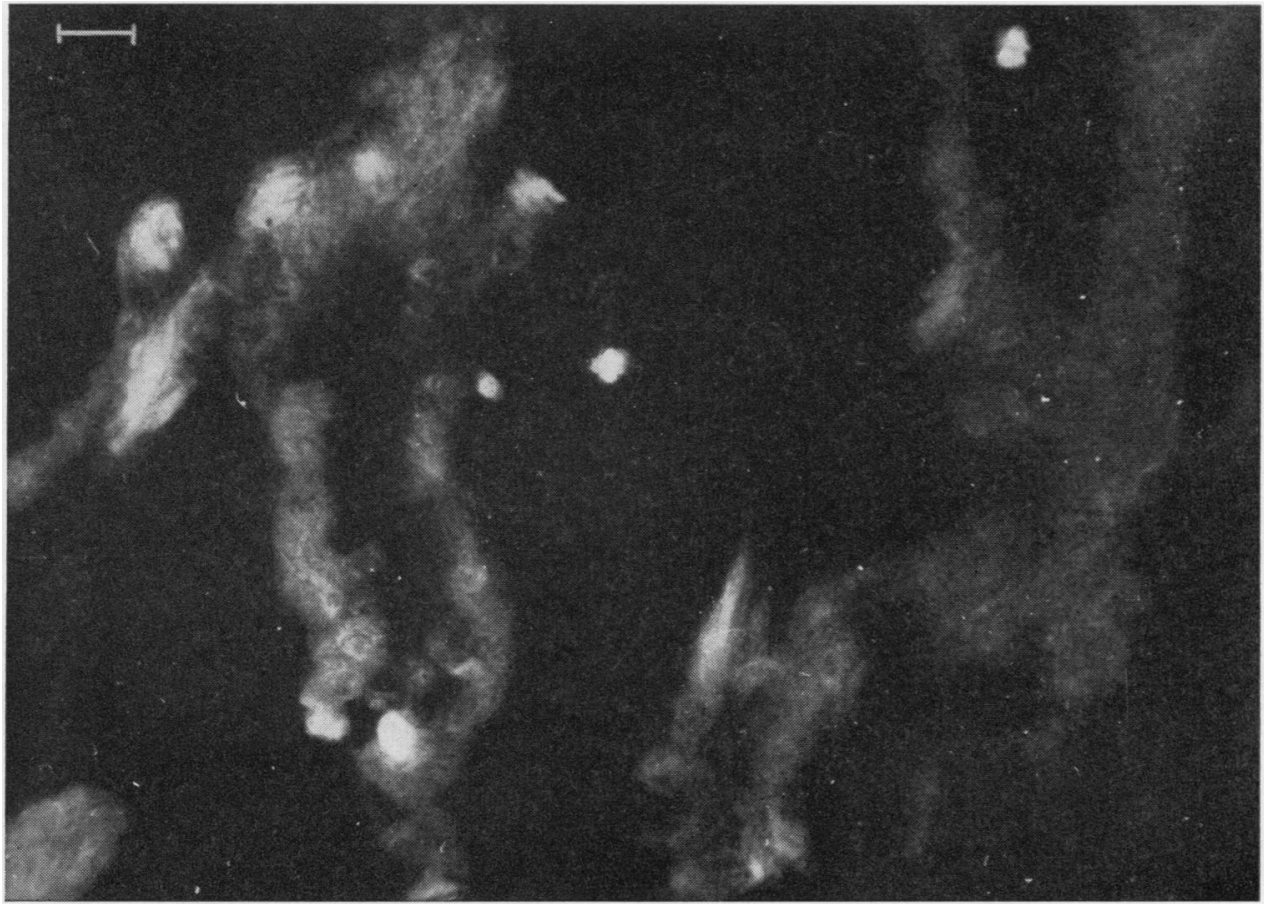

FIG. 2. Pulmonary alveoli showing only dim (yellowish) non-specific fluorescence (calibration $10 \mu)$. 


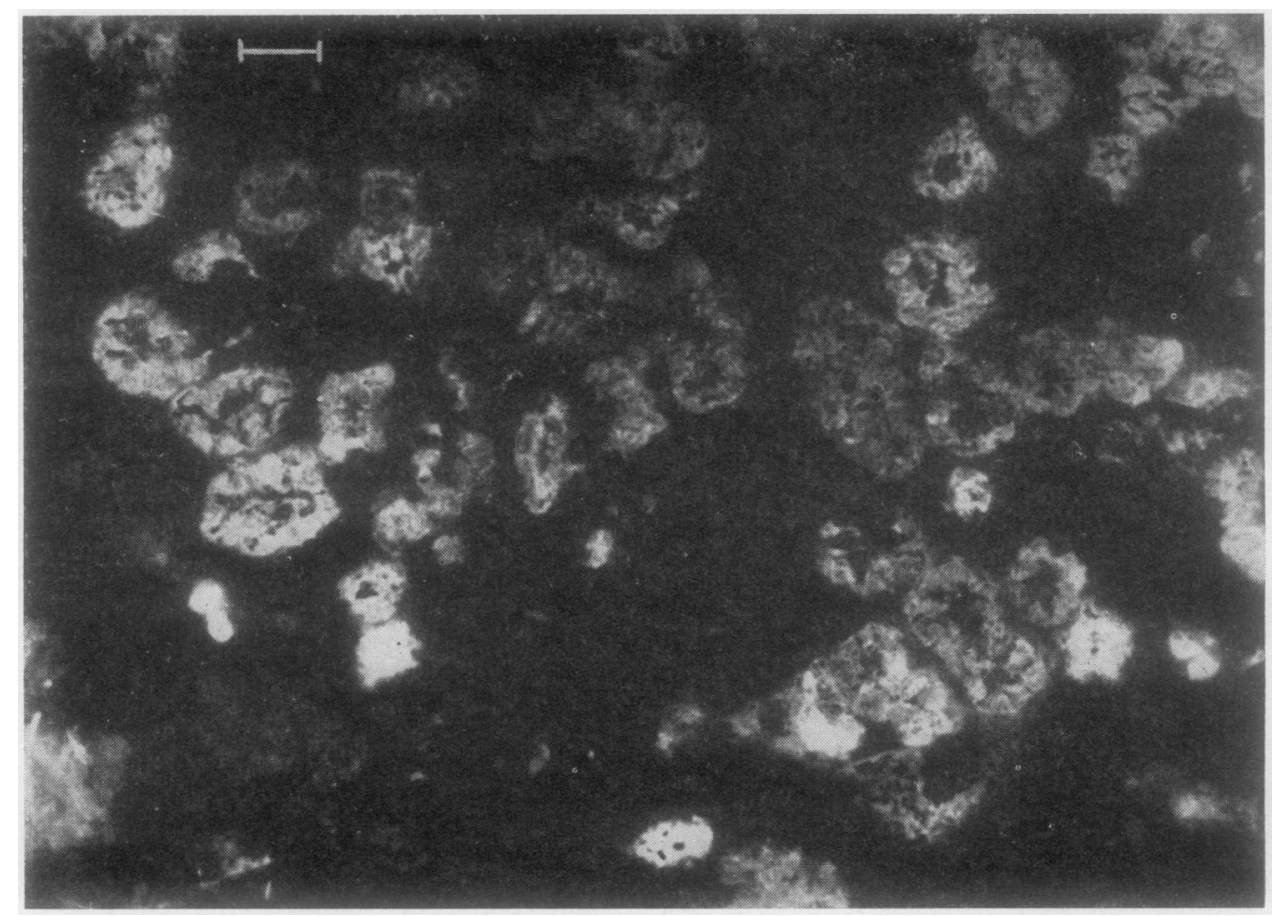

FIG. 3. Section through a cluster of glandular acini showing bright specific fluorescence characteristic of the presence of lactoferrin (calibration $50 \mu$ ).

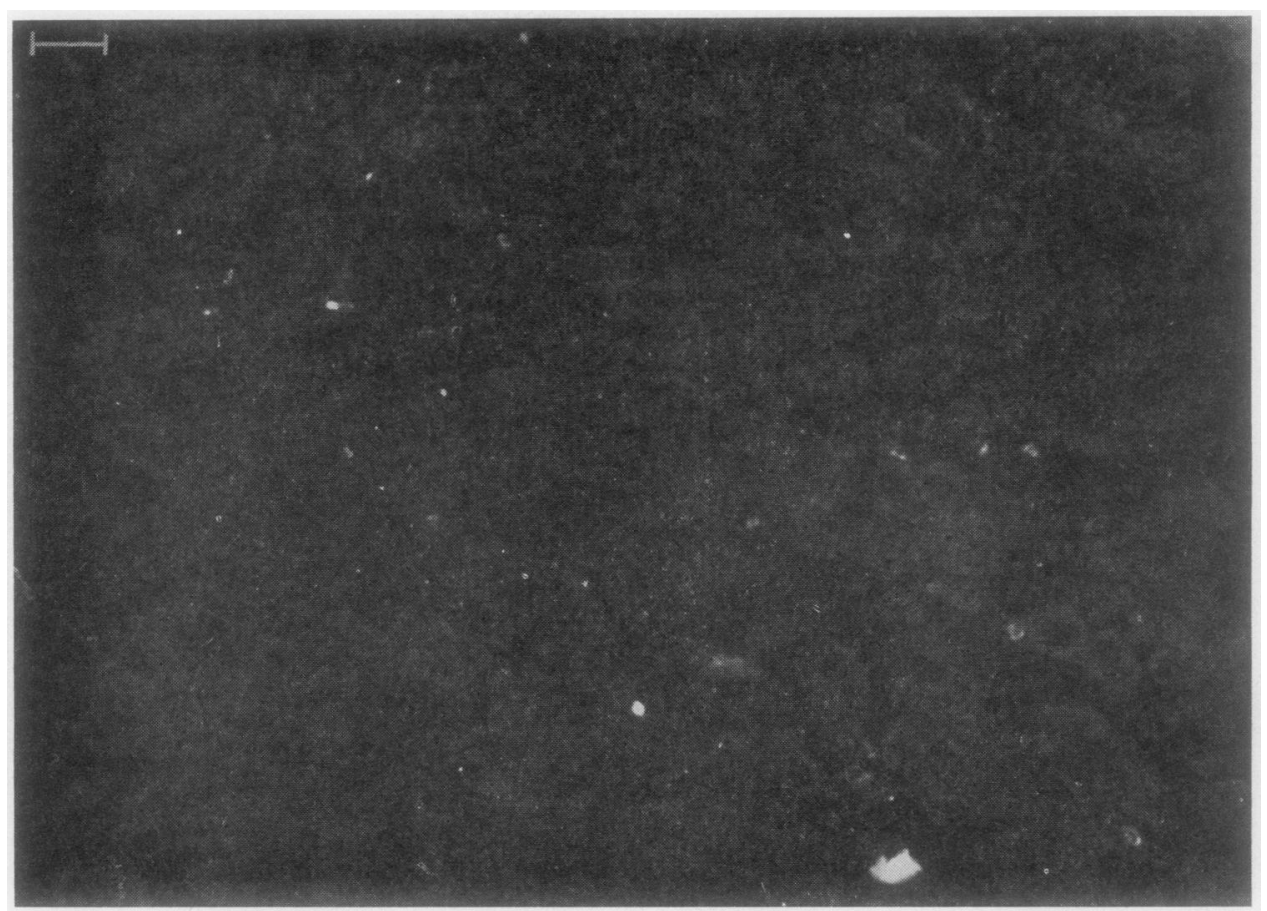

FIG. 4. Control section stained with antiserum which had been absorbed with lactoferrin. No fluorescence is observed, though many glandular acini are present in this field. 
used was a $0.02 \mathrm{M}$ phosphate buffer of $p \mathrm{H} \quad 7 \cdot 0$. Electrophoretic and immunoelectrophoretic controls proved the lactoferrin used for these experiments to be free of any contaminating proteins with known bacteriostatic effects, such as immunoglobulins, serum-transferrin or lysozyme.

The paper discs were applied on the surface of nutrient agar gel seeded with two species of bacteria, Staphylococcus albus and Staphylococcus aureus. Bacteriostatic activity was assessed from the size of the area of growth inhibition noted around the discs.

\section{RESULTS}

IMMUNOHISTOCHEMICAL LOCALIZATION OF LACTOFERRIN IN BRONCHOPULMONARY STRUCTURES No fluorescence was observed in the epithelial lining from the trachea, the bronchi (Fig. 1) of all sizes, or the bronchioles. The alveolar walls showed only a weak yellowish, non-specific fluorescence under ultraviolet illumination (Fig. 2).

In contrast, bright apple-green fluorescence was present in all glandular acini from all biopsies studied (Fig. 3). The specificity of this fluorescence was proved by the extinction of the reaction after absorption of the antiserum (Fig. 4) by the addition of lactoferrin $(2 \mathrm{mg}$. lactoferrin $/ \mathrm{ml}$. fluorescein-labelled antiserum).

From one glandular structure to another, large variations were observed in the intensity and mode of distribution of the specific fluorescence (Figs 5 and 7). In some of the glands practically all the cells had their cytoplasm completely and rather homogeneously filled with strongly fluorescent material. In other glands the fluorescence was restricted to a peripheral seam, whereas a third variety of acini displayed a combination of both modes of distribution. A fourth aspect consisted of a coarsely granular, somewhat streaky, and weaker type of specific fluorescence, with or without a strongly fluorescent peripheral seam.

The interpretation of these findings was assisted by a comparative scrutiny of the same fields, first under ultraviolet light and next by ordinary illumination after application of the periodic acid-Schiff stain (compare Figs 5 and 6, and 7 and 8). Obviously, all parts of acini exhibiting dense filling with strongly fluorescent material consisted of groups of cells displaying the features ordinarily attributed to serous cells (Policard and Galy, 1945). Conversely, wherever a brightly fluorescent peripheral rim was observed in the absence of noticeable centrally located fluorescence, the structure proved to consist of mucous cells. Occasional, peripherally situated patches of bright fluorescence belonging to otherwise nonfluorescent acini usually turned out to correspond to what is commonly described as 'serous crescents of Gianuzzi'. Weak granular fluorescence was associated with the strongly P.A.S.-positive cytoplasm of spumous and reticular appearance of mucous cells. Absence of fluorescence in the apical part of an acinar cell corresponded either to an optically empty vacuole or to an agglomerate of P.A.S.-positive mucinous material.

BACTERIOSTATIC ACTIVITY OF LACTOFERRIN At the concentration employed $(0.5 \%)$, lactoferrin clearly inhibited the growth of Staph. albus without impairing the development of Staph. aureus (Fig. 9).

This inhibitory activity on Staph. albus was progressively abolished by the addition of increasing amounts of ionized iron to the lactoferrin solution applied on the discs (Fig. 10).

\section{DISCUSSION}

The immunohistochemical data here presented give additional strength to our previous demonstration (Masson et al., 1965b) that lactoferrin is secreted by the bronchial tree. The cellular origin of this protein could be traced to the glandular acini, whereas neither the epithelial lining nor the alveolar walls appeared to take part in its production. Both the serous and mucous cells contained lactoferrin, so that no clearcut functional differentiation between both types seemed warranted on this basis. In serous cells, the lactoferrin was present in large amounts and appeared to be uniformly distributed over the entire cytoplasm. In mucous cells, lactoferrin was largely restricted to the basal part of the cytoplasm, creating the aspect of a brightly fluorescent peripheral rim around the acini predominantly consisting of cells of this type. The apical part of the cytoplasm of mucous cells was either devoid of lactoferrin or contained only moderate amounts of this protein, the latter being anatomically distinct from the strongly P.A.S.-positive mucus.

The bacteriostatic effect of lactoferrin on Staph. albus was obvious, although apparently much inferior to that which would be exerted by any of the antibiotics presently in use, employed at similar concentrations. It must be observed, however, that the disc method used here is largely dependent on the diffusion coefficient of the material to be tested. In this respect a substance of large molecular weight $(90,000$ in the case of lactoferrin) would obviously be at a big disad- 


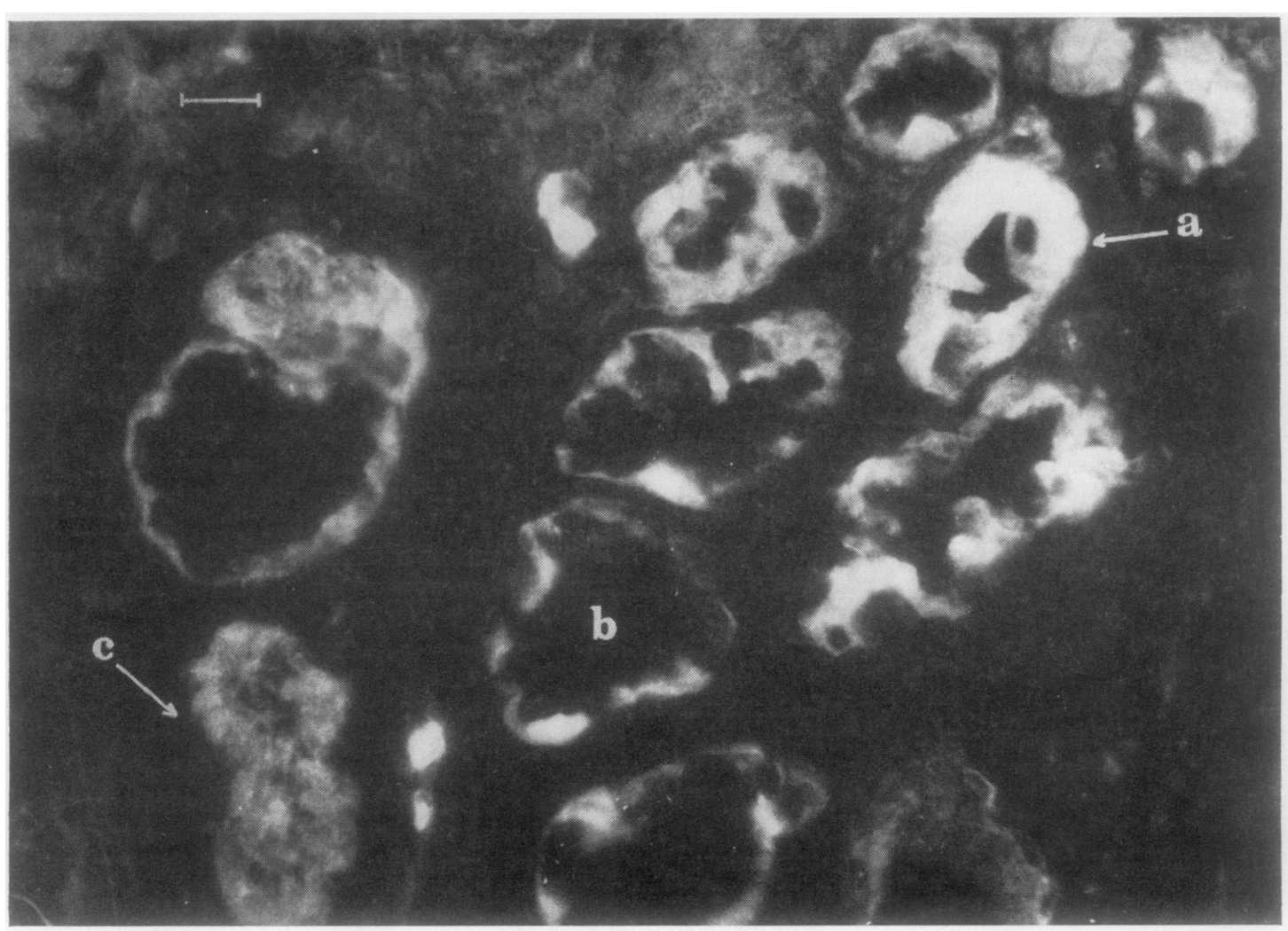

FIG. 5. Several glandular acini viewed at high magnification after staining with fluorescent antiserum (calibraz tion $20 \mu) ;$ a, acinus showing intense, homogeneous fluorescence of all cells; $b$, acinus with fluorescencè. restricted to a peripheral seam; c, acinus with granular type of fuorescence.

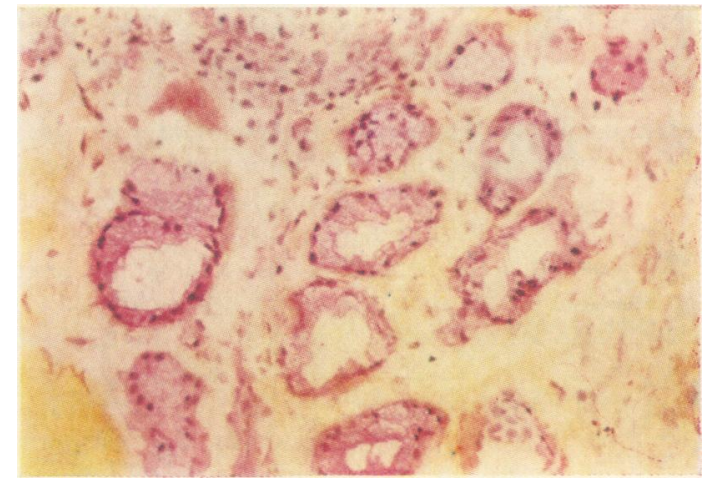

FIG. 6. Same field of same preparation as Fig. 5. Periodic acid-Schiff stain. The structure labelled (a) consists of serous cells, the ones labelled $(b)$ and $(c)$ of mucous cells. 


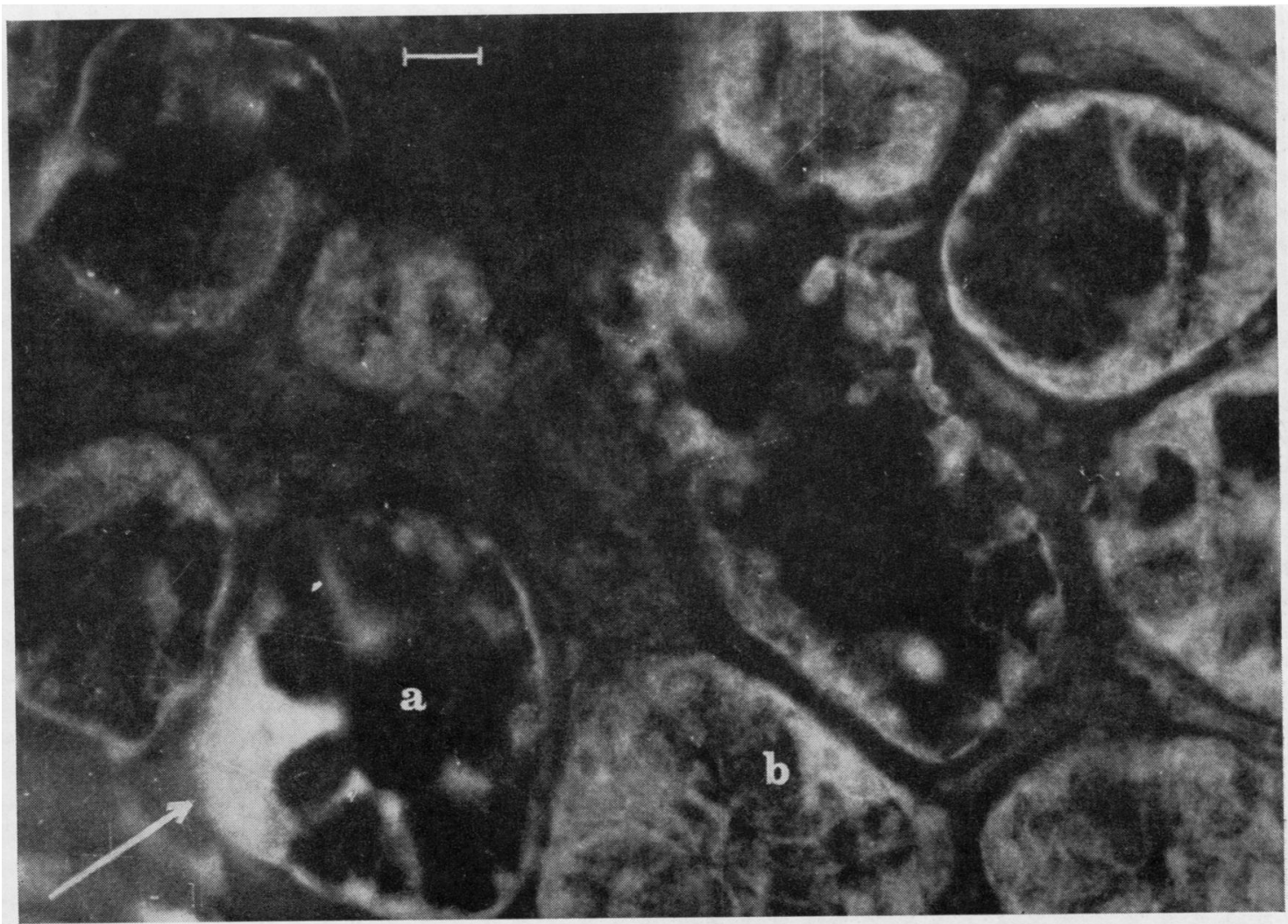

FIG. 7. Various types of acini at high magnification, fluorescent antiserum stain (calibration $10 \mu$ ); a, acinus with fluorescent crescent (arrow) and peripheral seam; $b$, acinus with radial distribution of fluorescence.

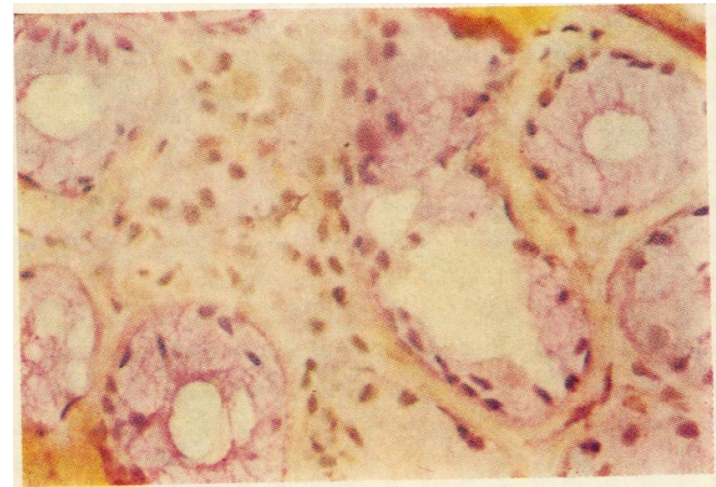

FIG. 8. Same field of same preparation as Fig. 7. Periodic acid-Schiff stain. The fluorescent wedge in acinus (a) corresponds to a serous crescent of Gianuzzi. vantage in comparison with a small molecule such as that of a tetracycline. Moreover, no precaution was taken to avoid the presence of iron in the nutrient medium employed for the cultures, so that it may be assumed that the saturation ratio of the lactoferrin was higher in these in vitro tests than would be the case in bronchial secretions in vivo. For both reasons one may surmise that lactoferrin plays a significant role as a bacteriostatic agent in the secretions where it occurs.

The fact that the inhibitory properties of lactoferrin vanished after the protein had been saturated with iron indicate that the bacteriostatic effect was related to the chelation of ionized iron from the medium, as has been shown by Schade (1961) for serum-transferrin. It is further interesting that both transferrin (Schade, 1961) and lactoferrin inhibited the development of Staph. 


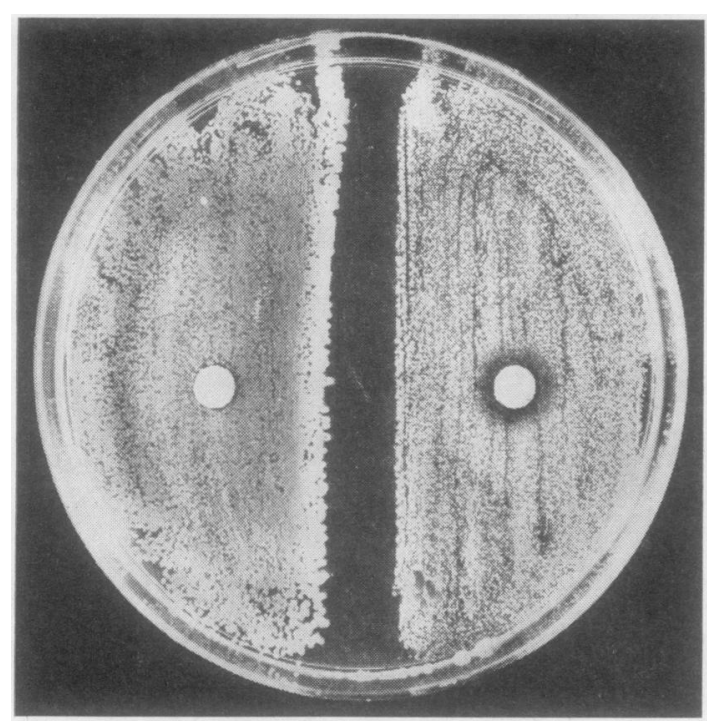

FIG. 9. Petri dish with left half seeded with Staph. aureus and right half with Staph. albus. Both paper discs were soaked in a $0.5 \%$ lactoferrin solution. Bacteriostatic effect is restricted to Staph. albus.

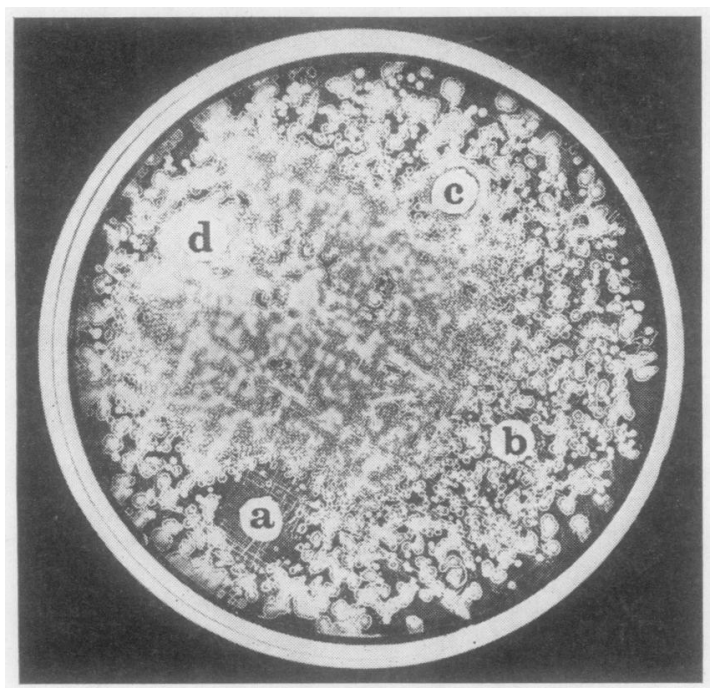

FIG. 10. Effect of addition of iron on bacteriostatic activity of lactoferrin towards Staph. albus; $a$, no iron added; $b, c, d$, addition of increasing amounts of iron. albus but not of Staph. aureus, an organism which $\frac{\bar{C}}{\overline{0}}$ is known to possess iron-binding receptors with sufficient activity to compete with those of thee iron-binding proteins investigated in these experi-ês ments.

\section{SUMMARY}

Lactoferrin, an iron-binding protein present in bronchial secretions, milk, and saliva but absent from the serum, has been investigated with regardi to its site of origin in the bronchial tree. Frozenos biopsy sections were incubated with fluorescein- if labelled antiserum specifically reacting with lacto- $\infty$ ferrin. This protein was present in all bronchial윽 glands. Both serous and mucous cells, especially $=$ the former, appeared to be involved in the $Z$ production of lactoferrin.

Purified lactoferrin exhibited a bacteriostatic $\frac{\Phi}{3}$ activity against Staph. albus but not against只 Staph. aureus. This effect appeared to be due to $\overrightarrow{0}$ the iron-binding properties of the protein, since it could be abolished by supplying an excess of ionized iron to the medium.

This investigation was supported by Grant No. $585 \bar{\partial}$ from the Fonds de la Recherche Scientifique@ Médicale, Brussels, Belgium. The authors are indebted $\stackrel{\mathbb{\Phi}}{\AA}$ to Dr. F. Meersseman for assistance with the $\vec{F}$ histological work.

\section{REFERENCES}

Biserte, G., Havez, R, and Cuvelier, R. (1963). Glycoprotéides des? sécrétions bronchiques. Expos. ann. Biochim. méd., $24 \mathrm{e}$ série pp. 85-120.

Blanc, B., and Isliker, H. C. (1961a). Isolement et caractérisation de lå protéine rouge sidérophile du lait maternel: la lactoferrine. Helv physiol. pharmacol. Acta, 19, C-13.

(1961b). Isolement et caractérisation de la protéine rouge sidérophile du lait maternel: la lactotransferrine. Bull. Soc. Chim. biol. (Paris), 43, 929.

Johansson, B. (1958). Chromatographic separation of lactalbumin from human milk whey on calcium phosphate columns. Nature 0 181, 996.

Masson, P. L., Carbonara, A. O., and Heremans, J. F. (1965). Studies on the proteins of human saliva. Biochim. biophys. Acta (Amst.) 107, 485 .

_- Heremans, J. F., and Prignot, J. (1965a). Immunohistochemica localization of the iron-binding protein lactoferrin in humano bronchial glands. Experientia (Basel), 21, 604. (1965b). Studies on the proteins of human bronchia secretions. Biochim. biophys. Acta (Amst.), 111, 466.

Montreuil, J., Tonnelat, J., and Mullet, S. (1960). Préparation etW propriétés de la lactosidérophiline (lactotransferrine) du lait de्ठ
femme. Ibid., 45, 413 .

Policard, A., and Galy, P. (1945). Les Bronches: Structures et mécalo nismes à l'état normal et pathologique, p. 64. Masson, Paris.

Schade, A. L. (1961). The microbiological activity of siderophilin. In Protides of the Biological Fluids: Proc. 8th Colloquium, Bruges? 1960, ed. H. Peeters, p. 261. Elsevier, Amsterdam. 